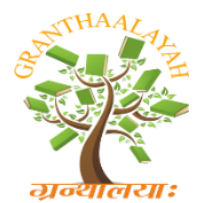

\author{
INTERNATIONAL JOURNAL OF RESEARCH - I \\ GRANTHAALAYAH \\ A knowledge Repository
}

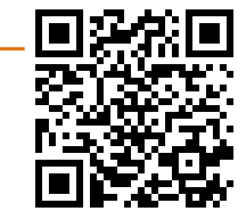

Science

\title{
AYURVEDIC CONCEPT OF KOSHTHA AND ITS IMPORTANCE IN PANCHKARMA
}

\author{
Dr. Shriram Shivajirao Ragad $* 1$, Dr. Maya Vivek Gokhale ${ }^{2}$ \\ ${ }^{*}$ M.D. Panchakarma (Scholar). Department of Panchkarma, Sumatibhai Shah Ayurveda \\ Mahavidyalaya, Hadapasar, Pune, India \\ ${ }^{2}$ M.D (Panchakarma), PhD (Kayachikitsa) HOD \& Professor, Department of Panchkarma, \\ Sumatibhai Shah Ayurveda Mahavidyalaya, Hadapasar, Pune, India
}

\begin{abstract}
Ayurveda is the science of life. Panchakarma procedure comes under the shodhana chikitsa. Shodhanaa chikitsa is better than shamanaa chikitsa, because disease treated with shodhana therapy will never reoccur. Koshtha, Agni, bala are the assessment factor in Panchakarma. The term koshtha can be described in two ways. koshtha is nature of digestive tract or hollow parts of body which represents motility of the intestines and movement of food and fecal matter in the alimentary canal and elimination of stool. koshtha shodan is most important procedure in Panchakarma. Assessment of Koshtha is very important for Panchakarma therapy as Dosage of Shodhana drugs are dependent upon type of Koshtha. If Koshtha Assessment does not properly done then Samyak shodhan does not occur.
\end{abstract}

Keywords: Koshtha; Shodhana Chikitsa; Virechan Karma; Tridosha.

Cite This Article: Dr. Shriram Shivajirao Ragad, and Dr. Maya Vivek Gokhale. (2019). "AYURVEDIC CONCEPT OF KOSHTHA AND ITS IMPORTANCE IN PANCHKARMA." International Journal of Research - Granthaalayah, 7(7), 416-421. https://doi.org/10.29121/granthaalayah.v7.i7.2019.808.

\section{Introduction}

There are two types of treatment in Ayurveda called as shodhana and shamana. ${ }^{(1)}$ shodhana is the method of eliminate the aggravated doshas from the body and purifying it, on other hand shamana it is to mitigate the aggravated doshas within the body itself. Assessment of koshtha play important role in Panchakarma procedure.

The term koshtha is explained in 2 senses in Ayurveda. Anatomically koshtha means the space or hollowness of the body for accommodation of organs including stomach, liver, spleen, pancreas intestine etc and pelvic cavity for accommodation of uterus, urinary bladder lower part of bowel etc called koshtha. Physiologically the koshtha is defined as bowel movement according to the basic constitutions of the person. ${ }^{(2)}$ 


\section{Aim and Objective}

- To Study the Importance of Koshtha in Panchakarma.

- To prove the importance of koshtha in Different Cases of Virechan.

\section{Types of Koshtha}

There are three types of koshtha based on predominance of doshas such as :(3).

Table 1: Showing Relation Between Koshtha- Dosh and Panchakarma Chikitsa.

\begin{tabular}{|l|l|l|l|}
\hline & Types of koshtha & Dosha & Shodhanaa chikitsa \\
\hline $\mathbf{1}$ & Krura (Hard) & Vata & Basti \\
\hline $\mathbf{2}$ & Mrudu (Soft) & Pitta & Virechana \\
\hline $\mathbf{3}$ & Madhya (Moderate) & Kapha & Vamana \\
\hline
\end{tabular}

\section{Krura Koshtha (Hard bowel):}

In krura koshtha vata is predominant dosha, increase of vata produces hard faeces with difficulty of elimination or even non-elimination. koshtha is dominated mainly by ruksha and khara gunas (qualities) of vata dosha over the sar guna of pitta dosha. Hence, krura koshtha will be poorly secretive and absorptive.

\section{Mrudu Koshtha (Soft bowel):}

In mrudu koshtha pitta is Predominant Dosha, increase of pitta causes watery or semi-solid faeces, moving out more than once or twice, in a day. Mrudu koshtha is characterized by sara (laxative), drava (fluid property), snigdha (unctuousness), and laghu (lightness) guna of pitta dosha. Hence the koshtha will be smooth, lubricated and slippery. Secretions will be more, but it will be poor in absorption.

\section{Madhyam Koshtha (Moderate bowel):}

In madhyam koshtha, kapha is Predominant Dosha. Increase of kapha causes soft, solid faeces moving out smoothly. In madhyam koshtha, there will be predominance of snigdha, guru (heaviness) and sthira (stable) guna. Koshtha will be secretive and will have more lubrication, but less slippery due to guru and sthira guna of kapha. Madhya koshtha, which is due to the samavastha of three doshas, there will be optimum secretion and absorption.

\section{Samakoshtha-}

Ashtanga-hrudya (Vagbhata) has mention four types of koshtha. ${ }^{(4)}$ Along with previous 3 types of Koshtha. Sama Koshtha having dominance of tridosha having Agni is Samagni which is influenced by perfect balance of tridosha where person will having proper digestion will pass out normal stool

For the vata, pitta, kapha doshas of body basti (enema), vireka (purgation) and vamana (emesis) are the best therapies respectively, use of medicinal oil (both internally and externally is ideal for mitigating vata, ghee for mitigating pitta and honey for kapha. 


\section{Koshtha And Virechana}

Koshtha is the expression of bowel habit, which depends on Prakriti (constitution). Generally, a subject with complaints of constipation is considered as Krūra koshtha produces dry and hard bowels Requires drastic purgatives of snigdha, ushna \& lavana like Shama, Kushta, Triphala. ${ }^{(9)}$ while in mrudu koshtha Minor laxatives easily induces diarrhea. Kshir (milk), Aaragwadha, ekshu, takra, mastu, gudha, krushara, navamadya, ushnodak, draksha ${ }^{(10)}$ and in madhyam koshtha requires kashaya \& tikta laxatives Requires medium purgatives of katu rasa and medium dose of Purgatives and laxatives. Doesn't purge by milk or minor laxatives.

koshtha and virechana dravya.

Table 2: Showing Types of Koshtha \& their Virechana Dravyas.

\begin{tabular}{|l|l|l|}
\hline $\begin{array}{l}\text { Sr. } \\
\text { No. }\end{array}$ & Koshtha & Virechana Dravyas \\
\hline $\mathbf{1}$ & Krura Koshtha & Eranda Tail, Haritaki, Triphala. \\
\hline $\mathbf{2}$ & Mrudu Koshtha & $\begin{array}{l}\text { Kshir (Milk), Aaragwadha, Ekshu, Takra, Mastu, Gudha, Krushara, } \\
\text { Navamadya, Ushnodak, Draksha }\end{array}$ \\
\hline $\mathbf{3}$ & $\begin{array}{l}\text { Madhyama } \\
\text { Koshtha }\end{array}$ & \begin{tabular}{l} 
Requires Kashaya \& Tikta Laxatives \\
\hline
\end{tabular} \\
\hline
\end{tabular}

\section{Importance of Koshtha Pariksha in Shodhana Chikitsa}

- We understand the prakruti by koshtha parikshana, Example - mrudu koshtha person having pitta prakrutti.

- To understand where the diseases is koshtha gata or shakhagata or Madhyama.

- Its help to decide samprapti of disease, either doshas going koshtha to shakha or vice versa.

- In shamanaa and shodhana chikitsa assessment of koshthais important to decide Aushadhi dravyas and Aushadhi matra. E.g. Mrudu koshthapersons require soumya aushadhi in minimum dose. Krura Koshtharequire Teeksha aushadhi in large dose. Same as krur koshtha required tikshna dravya virechana.

- Before Shodhanaa Karma, Snehapana is one of Purvakarma. Sneha-dravya and snehamatra (dose) can be decided by Koshtha-Pariksha. eg. Duration of snehapan in mrudu koshtha is 3 days.

- After Panchakarma observation of doshas, is doshas going shakha to koshtha or not.

- koshtha pariksha also helps To understand the Ahar-vihar

\section{Discussion}

Koshtha is most important concept which useful in different aspect of treatment part. Unfortunately, very few research occurs related to koshtha concept with Reference to shodhan chikitsa. Understand the relation of prkruti-agni- koshtha is important. Pachakrma is unique part of Ayuvedic treatment. In this pachakrma selection of drug as per patient is depend on koshtha.

\section{Koshtha and Agni}

Ayurveda give importance to concept called as Agni, which is also known as belly fire. This Agni is located in Amashaya, where partial digestion takes place in pakwashaya and grahni (small 
intestine and duodenum). The koshtha or gut behavior also follows this Agni. Following table shows relationship between Agni and koshtha according to predominance of doshas. ${ }^{(6)(7)}$

Table 3: Showing Relationship Between Agni and Koshtha According to Predominance of Doshas

\begin{tabular}{|l|l|l|l|}
\hline Sr.no. & Types of koshtha & Dosha & Agni \\
\hline $\mathbf{1}$ & Krura (Hard) & Vata & Visham \\
\hline $\mathbf{2}$ & Mrudu (Soft) & Pitta & Tikshna \\
\hline $\mathbf{3}$ & Madhya (Moderate) & Kapha & Manda \\
\hline
\end{tabular}

\section{Relationship between Krur koshtha -Agni with Doshas:}

The krur koshtha Predominant dosha is vata. In Vata Prakruti Agni is vishama means it is uneven in the function of digestion

\section{Relationship between Mrudu koshtha -Agni with Doshas:}

The mrudu koshtha Predominant dosha is pitta. Pitta and Agni are the same in properties so the food digest quickly. There is frequency for bowel is clear formation of soft stool.

\section{Relationship between Madyam koshtha -Agni with Doshas:}

The madyam koshtha predominant dosha is kapha the digestion of in this type of Agni will be mild to moderate so the formation of stool is neither to hard nor to soft it is normal. this type of koshtha found in healthy people

\section{Analysis of Koshtha}

This finding may be misleading as this may be an acquired condition and so it is important to distinguish between what is constitutional and what is acquired. Constitutional means the nature of bowel habit since from birth.

The bowel habits were examined in following way-

- Frequency

- Consistency, straining or efforts

- Time taken for proper defecation

- Satisfaction

- Previous encounters of diarrhea and constipation

- Previous experiences of purgatives and laxatives.

- The above points regarding the Malapravritti were considered for the assessment of Koshţha.

Table 4: Showing Analysis of Koshtha with Different Point

\begin{tabular}{|l|l|l|l|l|}
\hline Koshtha & $\begin{array}{l}\text { Duration of } \\
\text { Snehapana }\end{array}$ & Malapravrutti & $\begin{array}{l}\text { Aaharshakti \& } \\
\text { jaranshakti }\end{array}$ & Duration \\
\hline $\begin{array}{l}\text { Krura } \\
\text { Koshtha }\end{array}$ & 7 days & $\begin{array}{l}\text { Hard and dry } \\
\text { stools }\end{array}$ & $\begin{array}{l}\text { vishama (irregular } \\
\text { frequency and } \\
\text { quantity) }\end{array}$ & $\begin{array}{l}\text { Doesn't pass stool } \\
\text { regularly }\end{array}$ \\
\hline
\end{tabular}




\begin{tabular}{|l|l|l|l|l|}
\hline $\begin{array}{l}\text { Mrudu } \\
\text { koshtha }\end{array}$ & 3days & $\begin{array}{l}\text { Semi formed or } \\
\text { formed stool }\end{array}$ & $\begin{array}{l}\text { Tikshna (more } \\
\text { frequency and } \\
\text { quantity) }\end{array}$ & $\begin{array}{l}\text { Passes Stools } \\
\text { daily once or } \\
\text { twice regularly, }\end{array}$ \\
\hline $\begin{array}{l}\text { Madhyama } \\
\text { koshtha }\end{array}$ & 5 days & $\begin{array}{l}\text { normal } \\
\text { stools }\end{array}$ & Manda (less) & $\begin{array}{l}\text { Passes stools daily } \\
\text { once, }\end{array}$ \\
\hline
\end{tabular}

\section{Analysis of Dose of Virechan Drug \& Veg of different Patient}

Table 5: Showing Analysis of Dose of Virechana Drug \&Veg in Different Patient

\begin{tabular}{|l|ll|}
\hline DOSE & \multicolumn{2}{|c|}{ Patient -Antiki pariksha } \\
\hline Abhayadi modak Tab.2 & 13 & Kaphanta \\
\hline Abhayadi modak Tab.2 & 33 & Kaphanta \\
\hline Abhayadi modak Tab.3 & 16 & Kahpanta \\
\hline Abhayadi modak Tab.3 & 35 & Kaphanta \\
\hline Abhayadi modak Tab.4 & 22 & Kaphanta \\
\hline Abhayadi modak Tab.4 & 35 & Kaphanta \\
\hline
\end{tabular}

The above table shows that same dose of virechan drug was given to patient but the number of vega in those patients were different because Vega depends upon koshta of Patients. Here is the Analysis of 6 patients who had been given virechan treatment. Abhayadi modak was virechak dravya given to all these 6 patients. From that study it was observed that-with intake of 2 tablets of abhayadi modak, one patient got 13 virechana vega; while other patient got 35 virechan vega. To another patients with intake of 3 tablets of abhayadi modak one patient got 22 virechan vega while other patient got 35 virechan vega. To another patients with intake of 4 tablets of abhayadi modak, one patient got 16 virechan vega while other patient got 35 virechana vega.

From above table it can be concluded that though the same dose of virechan dravya was administered in different patients resulted in different number of vega. The factor which was different in patients was koshtha due to which different vega occurred. This show that study of koshtha is important. Before selection of dose of drug for virechan or any panchakarma.Assesment of koshtha is important otherwise the vyapad like Ayog or Atiyog will be seen in patient.

So, in above table the patients who had been given 2 tablets where of mrudu koshtha still the symptom of kaphanta which is of samyak shodhan was observed. The patient who showed 13 vega of madhyam koshtha \& 33 vega of mrudu koshtha.in the same way where 4 tablets were administered patient showed 35 vega. As the patient was krura koshtha after 4 tablets the vega were 35 kaphant symptom occurred. While as previous patient showed 33 number of vega by 2 tablets. This proves the important of koshtha after assessment of patient koshtha the mrudu koshtha patient given 2 tablet while krur koshtha patient given 4 tablet both showed symptom of samyak virechan, So assessment of koshtha is very important not only in virechan but also in Vaman \& Basti. For Basti also mrudu koshti patient given less amount of basti dravya the amount of Sneha \&madhu is adjusted accordingly in vaman also for mrudu koshthi patient the madan phal matra is adjusted accordingly too avoid atiyog this is the importance of koshtha in panchakarma. 


\section{Conclusions}

koshtha is the basic and important concept in Ayurveda. Koshtha plays an important role in selection the line of treatment of disease. koshtha parikshan is required before shodhana treatment. For selection of drug matra anupan, snehapan koshtha assessment is necessary. In short, this review paper highlights the concept of koshtha and its importance in panchkarma.

\section{References}

[1] Dr.k.r.shrikantha murthy,Astang hrudayam English commentary.published by krishnadas academy edition fifth, choukhamba Sanskrit series, vol $1^{\text {st }}$; sutra-stan ayushkamiy adhyaya ; chapter-1, verse no- 25 ; page no. 14

[2] http://easyayurvda.com (25 may 2019; $11.30 \mathrm{am})$

[3] Dr. Anant Ram Sharma, edited with 'susrutavimarsini' Hindi commentary. (Ed.). Susruta samhita, maharshi susruta. Chikitsastan; vamanvirechanasadhyoupadrava-adhyaya: Chapter-33, verse no20, Varanasi: Chukhambha prakashan : 2010 ; page no.427.

[4] Dr. Ganesh Krushana garde, (12 ${ }^{\text {th }}$ Ed.), Sartha vagbhat,vagbhtakryta ashtang-hrudhaya and its Marathi translation, Sutrastan; Ayushyakamiya-Adhya ; chapter-1, verse no-8 ; pune : profesent publishing house :2009; page no.2.

[5] Dr.k.r.shrikantha murthy,Astang hrudayam English commentary.published by krishnadas academy edition fifth, chowkhamba Sanskrit series, vol $1^{\text {st }}$; sutrastan ayushkamiy adhyaya ; chapter-1, verse no-26; page no.14

[6] http://easyayurvda.com (25 may 2019; $11.30 \mathrm{am)}$

[7] Dr.k.r.shrikantha murthy,Astang hrudayam English commentary.published by krishnadas academy edition fifth, chowkhamba Sanskrit series, vol $1^{\text {st }}$; sutrastan ayushkamiy adhyaya; chapter 1 verse no.8 page no.06.

[8] Dr. Anant Ram Sharma, edited with 'susrutavimarsini' Hindi commentary. (Ed.). Susruta samhita,maharshi susruta. Chikitsastan;vamanvirechanasadhyoupadrava-adhyaya: Chapter 33.verse no.29.Varanasi : Chukhambha prakashan, 2010 ; page no.427.

[9] Dr. Ganesh Krushana garde, (12 ${ }^{\text {th }}$ Ed.), Sarthavagbhat, vagbhta charyaas ahtang-hrudhaya and its Marathi translation, Sutra-Stan; vaman-virechna-Adhya ; chapter-18. Verse no-34; pune : profesent publishing house, 2009 ; page no.88.

[10] Dr. Ganesh Krushana garde, (12 $2^{\text {th }}$ Ed.), Sartha vagbhat,vagbhtakryta ashtang-hrudhaya and its Marathi translation, Sutrastan; vaman-virechna-Adhya ; chapter 18. Verse no-33, hemadritika ; pune : profesent publishing house,2009; page no.88.

[11] Dr. Brahmananda Tripathi, Charak Samhita of maharshicharak, Chukhambha-prakashan, Varanasi, 2010, Sutra-sastan, $11^{\text {th }}$ adhya, verse no-48; page no. 246.

[12] Dr. BrahmanandaTripathi, Charak Samhita of maharshicharak, Chukhambh-aprakashan, Varanasi, 2010, Sutra-sastan, $11^{\text {th }}$ adhya, verse no-48; page no. 246.

[13] Patient Record from Virechan File 2018, Sane Guruji Arogya Kendra PUNE.

*Corresponding author.

E-mail address: shriramragad1992@gmail.com/drmayagokhale @gmail.com 